\title{
Insulin as a Growth Factor
}

\author{
D. J. HILL AND R. D. G. MILNER \\ Department of Paediatrics, University of Sheffield, Children's Hospital, Sheffield, England
}

\begin{abstract}
Insulin is a potent mitogen for many cell types in vitro. During tissue culture, supraphysiological concentrations of insulin are necessary to promote cell replication in connective or musculoskeletal tissues. Insulin promotes the growth of these cells by binding, with low affinity, to the type I insulin-like growth factor (IGF) receptor, not through the high affinity insulin receptor. In other cell types, such as hepatocytes, embryonal carcinoma cells, or mammary tumor cells, the type I IGF receptor is virtually absent, and insulin stimulates the growth of these cells at physiological concentrations by binding to the high affinity insulin receptor. Both receptor systems activate phosphorylation reactions within the cell which extend to ribosomal proteins. Insulin acts synergistically with other factors, such as platelet-derived growth factor and epidermal growth factor, to stimulate the progression of cells through the cycle of proliferation. Abnormal insulin secretion or action, before or after birth, often is associated with disordered growth suggesting that insulin may function as a growth factor in vivo. Poor growth follows impaired insulin secretion in diabetes mellitus. This is associated with reduced circulating levels of IGF's which may be partly responsible for the growth failure. Insulin has a direct action on release of IGF's from the liver in vitro, but during experimental diabetes there is a reduced number of hepatic somatotropic receptors which could limit the ability of growth hormone to regulate IGF release. Diabetic children, treated conventionally, have normal circulating IGF levels, but both growth rate and serum IGF concentration may increase dramatically when diabetic control is optimized. Hyperinsulinaemia in the human fetus of a diabetic mother may result in somatic overgrowth as well as adiposity, whereas experimental fetal (animal) hyperinsulinaemia does not result in skeletal overgrowth, and promotes IGF release only at extreme levels. Conversely hypoinsulinemia, with or without nutritional deprivation, is associated with fetal growth retardation accompanied by low circulating IGF levels. It can be concluded that insulin functions as a growth factor in both normal and abnormal development. Insulin promotes the growth of selected tissues by a direct action; in others, such as the musculoskeletal system, the action is indirect via the regulation of IGF release. (Pediatr Res 19: 879-886, 1985)
\end{abstract}

\section{Abbreviations}

IGF, insulin-like growth factors

MSA, multiplication-stimulating activity

Although insulin is mitogenic for most cell types during tissue culture, its role as a peptide growth factor has attracted less

Received March 18. 1985: accepted March 25, 1985.

Correspondence to Dr. D. J. Hill. Department of Paediatrics, University of Sheffield. Clinical Sciences Centre. Northern General Hospital. Sheffield S5 7AU. England. attention than its well known, acute metabolic actions. Insulin also can influence growth in vivo. The poor growth of a child with diabetes (1) contrasts with the overgrowth of the hyperinsulinemic infant of a diabetic mother (2). The growth-promoting effect of insulin in vivo was demonstrated experimentally by Salter and Best in 1953 (3); these investigators restored growth to hypophysectomized rats by treatment with insulin and a high carbohydrate diet. Rats given insulin grew as well as those given growth hormone but consumed substantially more food. Any analysis of the action of insulin in promoting growth must clearly separate those effects which are due to anabolism resulting from increased nutrient availability and utilization from those effects which are due to insulin being a member of a family of growthpromoting peptides.

The mechanisms by which insulin can act as a growth factor have become clearer with the discovery of the structure and biological actions of related molecules, the somatomedins or IGF. Two IGF have been isolated from human serum, IGF I (or somatomedin-C) and IGF II. Both molecules show greater than a $40 \%$ similarity in amino acid structure with insulin and are potent mitogens both in vitro and in vivo $(4,5)$. Rat serum contains IGF molecules showing a strong homology to human IGF I and II, the latter molecule in the rat is commonly known as MSA (6). In postnatal life the release of IGF, in particular IGF I which is the more potent growth-promoting peptide in vivo, are largely dependent on circulating growth hormone (4). However, disordered growth consequent to insulin dysfunction is frequently associated with a parallel change in circulating levels of IGF, suggesting a direct or indirect modulation of IGF production by insulin. Additionally, the similarity in structure between insulin and IGF's allows low-affinity binding between insulin and IGF cell membrane receptors and vice versa (7). Insulin may, therefore, exert direct mitogenic actions through either insulin or IGF receptors.

In this paper experimental evidence is reviewed which supports the concept that insulin has both direct and indirect roles in the control of normal body growth. Possible mechanisms of action are discussed in relation to clinical disorders of growth involving abnormal insulin release or action before and after birth.

\section{DIRECT ACTIONS OF INSULIN}

Insulin is added to hormone-supplemented culture media for a wide variety of cell types to achieve optimal cell replication (8). Supra-physiological concentrations, in excess of $1 \mu \mathrm{M}$, are required for the maximal proliferation of many cells, including those of the mesodermally derived connective tissues which contribute to much of the musculoskeletal system. At such high concentrations, insulin may mimic the growth-promoting actions of the IGF due to the strong structural homology between these peptides and limited cross-reactivity with their respective cell membrane receptors.

Insulin initiates biological responses by interaction with a high affinity insulin receptor on the cell membrane leading to internalization of the hormone-receptor complex and subsequent degradation of insulin by lysozomes (9). It appears that receptor occupation, rather than the insulin molecule itself, provides the initial impulse for a cellular response, since noninsulin ligands 
such as lectins and antiinsulin receptor antibodies also possess insulin-like activity $(10,11)$.

The insulin receptor has been highly conserved throughout evolution and between different tissues, and has a tetrameric structure consisting of two $\alpha$ subunits of molecular weight approximately $135 \mathrm{~K}$ daltons and two $\beta$ subunits of $95 \mathrm{~K}$ daltons. The subunits are linked by disulphide bonds (12). Affinity crosslinking of radiolabeled peptides to membrane proteins revealed two classes of receptors for the IGF. The type I receptor has a higher affinity for IGF I than IGF II, and binds insulin with low affinity (13). This receptor showed a close homology with the high affinity insulin receptor, but probably is a distinct gene product, the $\alpha$ subunit of the type I IGF receptor being $8 \mathrm{~K}$ daltons smaller than that for insulin (14). The IGF also interact with a second class of receptor, called type II, which binds IGF II with higher affinity than IGF I and binds insulin very poorly. The type II receptor is a single chain glycoprotein of molecular weight approximately $250 \mathrm{~K}$ daltons which is apparently unrelated to the type I or insulin receptor (14).

The supraphysiological concentrations of insulin necessary to induce the growth of connective tissues in vitro suggest that the biological response may be mediated by the type I IGF receptor. This was originally deduced from the observation that insulin competed with IGF's for binding to chick embryo fibroblasts, while the actions of the two peptides were nonadditive during the growth of these cells $(15,16)$. Furthermore, when the high affinity insulin receptor on human dermal fibroblasts was blocked with Fab fragments from antiinsulin receptor antibodies derived from a patient with extreme insulin resistance, it still was possible to demonstrate an insulin-dependent uptake of $\left[{ }^{3} \mathrm{H}\right]$ thymidine (17). Human fibroblasts contain type I IGF receptors which, presumably, mediated the actions of insulin on growth (13). This conclusion was supported by a failure of intact antiinsulin receptor $\mathrm{IgG}$ to promote thymidine uptake by fibroblasts in vitro despite its ability to mimic the acute metabolic actions of insulin which are mediated via the insulin receptor (17).

Conversely, insulin is mitogenic at much lower concentrations (less than $5 \mathrm{nM}$ which are in the physiological range) for a variety of cell types, including human mammary tumor cells, GH3 rat pituitary tumor cells, F9 embryonal carcinoma cells, and rat hepatocytes (18-22). The F9 embryonal carcinoma line grew in response to low concentrations of insulin or $\operatorname{MSA}(21,23)$. These cells are rich in type II IGF receptors and high affinity insulin receptors, but lack the type I IGF receptor $(20,21)$. Since the type II receptor binds insulin poorly, it is likely that the growth response to insulin in these cells is mediated by the insulin receptor. Accordingly, the actions of insulin could be reproduced by an antiinsulin receptor antibody (20). Similarly, the H35 rat hepatoma cell line multiplied with a half-maximal response in the presence of less than $200 \mathrm{pM}$ insulin (24). These cells also are rich in type II IGF receptors and lack type I receptors (25). An antibody to the type II receptor did not abolish the growth response to insulin or MSA reinforcing the opinion that the cellular message was mediated via the insulin receptor (26).

Since the relative distribution of receptors to the insulin-like family of peptides is similar on normal hepatocytes and the H35 hepatoma line (27), a direct growth-promoting action by physiological levels of insulin has relevance to liver regeneration. Although the hepatic portal circulation was shown to contain a hepatotrophic factor, liver regeneration was not seriously impaired by diabetes in the rat (28). When partially hepatectomized rats were eviscerated of all portally drained organs and maintained on an intravenous diet, the resulting hepatic DNA synthesis was only $20 \%$ of that in noneviscerated animals; however, the level of DNA synthesis increased toward control values after infusion of eviscerated rats with a combination of insulin and glucagon (29). Moreover, these hormones did not stimulate DNA synthesis in the intact rat liver suggesting that their role was to potentiate, rather than induce, liver regeneration. Studies in vitro showed insulin to be a mitogen for isolated rat hepatocytes at concentrations from $4 \mathrm{~nm}$ to $4 \mu \mathrm{M}$, and that insulin acted synergistically with epidermal growth factor (30). In the presence of both epidermal growth factor and glucagon, at concentrations of 3 and $7 \mathrm{nM}$ insulin was half-maximal in increasing DNA synthesis and cell number, respectively, in cultured hepatocytes (22). IGF I was half maximal at 1 and $5 \mathrm{nM}$, respectively, for the same parameters. Since rat hepatocytes have few IGF type I receptors, and the type II receptor has not been shown to mediate an intracellular anabolic signal, it seems likely that physiological concentrations of insulin or the IGF promote growth of isolated hepatocytes by interaction with the insulin receptor.

The binding of insulin to the insulin receptor on intact cells or isolated membrane preparations leads to phosphorylation reactions in serine, threonine, and tyrosine residues of several membrane proteins including the receptor glycoprotein (31). It appears that the insulin receptor contains within its structure a tyrosine-specific protein kinase which activates autophosphorylation of the receptor (32). The two functions of insulin binding and protein kinase activity are in different subunits: the $\alpha$ subunit containing the binding site and the $\beta$ subunit the kinase activity (33). The two subunits are linked by two disulphide bonds and readily communicate with one another, presumably by conformational changes, such that the binding of ATP to the $\beta$ subunit regulates the binding of insulin to the $\alpha$ subunit (34). Since the $\beta$ subunit is transmembranal, the induction of autophosphorylation by the binding of insulin to the $\alpha$ subunit may provide the first intracellular molecular signal. Similar tyrosine-specific kinases have been identified within the receptors for other peptide growth factors, including IGF, platelet-derived growth factor, epidermal growth factor, and the pp 60 transforming protein present following the infection of cells with Rous sarcoma virus (35-38).

It is hypothesized that many of the biological actions of insulin, including cell growth, may be mediated by phosphorylation cascade reactions (39), but the precise signals have yet to be determined. The stimulation of growth in mammalian fibroblasts leads to a rapid increase in cytoplasmic $\mathrm{pH}$ due to activation of a sodium/hydrogen ion exchange channel in the plasma membrane (40). This ionic exchange may be necessary before DNA synthesis can commence, and is initiated by the activity of a calcium and phospholipid-dependent protein kinase known as c-kinase (41). The c-kinase normally is activated by diacylglycerol, the final product in a cycle of membrane phosphorylation/dephosphorylation reactions commencing with phosphatidyl inositol (42). The introduction of phorbol esters, which are tumor promoters, into cell systems leads to an activation of ckinase and the phosphorylation of the $\beta$ subunits in both the insulin and IGF type I receptors, and to their subsequent internalization (43). Hence, both tumor promoters and peptide growth factors such as insulin may precipitate a change in intracellular $\mathrm{pH}$ by the activation of the PI cycle and c-kinase.

The stimulation of cell proliferation in quiescent cells after exposure to inulin, the IGF, epidermal growth factor, or plateletderived growth factor is accompanied by the phosphorylation of a ribosomal protein S6 (44). The phosphorylation of S6 has been suggested to be necessary for the transition of cells from a quiescent $G_{0}$ phase to the $G_{1}$ phase of the cycle of cell replication, and may cause an alteration in the affinity of ribosomes for messenger RNA. The pathway by which insulin and other peptide growth factors phosphorylate the $\mathrm{S} 6$ protein involves a cyclic AMP-independent protein kinase-promoting phosphate incorporation at serine residues (45). Since the same kinase activity also is activated by phorbol esters, the phosphorylation reactions directed at translational events following insulin stimulation may be linked to initial receptor occupancy and internalization by the phosphatidyl inositol cycle and c-kinase activation.

For many cells, the actions of insulin on growth are potentiated by the presence of other peptide growth factors. This was convincingly demonstrated for the BALB/c 3T3 cell where growthpromoting peptides could be classified as "competence" and 
"progression" factors (46). Competence factors, such as plateletderived growth factor, induced the biochemical changes necessary to progress from a quiescent $G_{0}$ phase to an active $G_{1}$ stage of the cell cycle. Once cells had been rendered competent they no longer required the presence of molecules such as plateletderived growth factor, but were dependent on peptides such as insulin or IGF for progression through $\mathrm{G}_{1}$ to $S$ phase and DNA synthesis. Insulin, IGF I, and MSA fulfilled a similar progression factor role during the latter part of $\mathrm{G}_{1}$, during which amino acid uptake and protein synthesis were greatly increased; however, in BALB/c-3T3 fibroblasts insulin was less active than the IGF (47). Insulin also appears to act as a progression factor during hepatocyte replication (48). The molecular basis of the concept of competence and progression, and hence the synergism between insulin and other peptide-growth factors, may derive from the observations that the binding of platelet-derived growth factor to its own receptor on BALB/c-3T3 cells induced rapid changes in the membranal expression of receptors to progression factors. For the epidermal growth factor receptor this involved a downregulation while receptors for the IGF were up-regulated (49, $50)$.

\section{MEDIATION OF GROWTH-PROMOTING ACTIONS OF INSULIN BY IGF'S}

The induction of severe diabetes in the rat by treatment with streptozotocin is associated with a cessation of growth and a negative nitrogen balance, both of which are reversible by insulin therapy. The growth retardation is associated with a rapid decline in the circulating levels of IGF, which can reach the low values found in hypophysectomized rats within $72 \mathrm{~h}$ of B-cell destruction. Although the initial observations were obtained by bioassay and were due, in part, to an increase in the circulating levels of an inhibitor of IGF action (51), an actual decrease in serum IGF I was confirmed by radioreceptor and radioimmunoassay (5254).

Although it has been suggested that the growth retardation seen in the diabetic rat is associated with normal levels of circulating growth hormone and prolactin, two major regulators of IGF release from rat liver $(55,56)$, a more detailed analysis of $\mathrm{GH}$ release indicated a depression in amplitude of growth hormone pulses within $18 \mathrm{~h}$ of streptozotocin administration (57). This was alleviated by treatment of diabetic rats with antisomatostatin antiserum, suggesting that an increase in somatostatin release from the hypothalamus may have contributed to the altered growth hormone secretion. However, treatment with growth hormone did not result in growth or an increase of circulating IGF levels in the diabetic rat (51) or the pancreatectomized $\operatorname{dog}(58)$, whereas insulin therapy resulted in an increase in both $(51,53,58)$.

One possible mechanism by which insulin may regulate growth is a direct modulation of tissue IGF release. Exposure to insulin resulted in an increase in IGF production from isolated rat hepatocytes (59), from liver slices $(60,61)$, and from the isolated, perfused rat liver (62). Although supraphysiological levels, in excess of $7 \mathrm{nM}$, generally were required, studies utilizing liver slices showed IGF release with as little as $10 \mathrm{pM}$ insulin. Perfusion of the liver from diabetic rats showed a deficiency in IGF release which was partly restored by pretreatment of the animal with insulin in vivo (63).

Insulin also may mediate IGF release from the liver indirectly by an alteration in the growth hormone/IGF axis, since both acute and mild nonketotic diabetes in the rat are accompanied by a severe reduction in the numbers of high affinity hepatic somatotropic receptors $(54,64)$. This was reversed by insulin treatment. Superficially this is analogous to the disruption in the growth hormone/IGF pathway that occurs in malnutrition, where hypoinsulinemia is accompanied by low circulating IGF levels despite, in the human, increased secretion of growth hormone (65-67). However, in the diabetic rat, the decline in circulating IGF and the reduction in hepatic growth hormone receptors may not be causally related. In the mildly diabetic rat, circulating IGF I levels were significantly reduced $1 \mathrm{wk}$ after the induction of diabetes, yet the hepatic binding capacity for growth hormone did not fall significantly for another 3 wk (54). Following treatment with insulin, serum IGF levels were quickly restored, but the somatotropic receptor population only partly so.

Growth hormone has been reported to down-regulate its hepatic receptor site (68), but recent evidence by Baxter et al. (69) suggests that the opposite may occur. Hence a reduction in the amplitude or frequency of the episodes of growth hormone release in the diabetic rat may reduce the number of high affinity somatotropic receptors in the liver. Both this and a directly mediated decline in insulin-dependent IGF release would result in a lowering of circulating IGF in response to hypoinsulinism and a failure to grow. However, the relative unimportance of an extended pathway involving pituitary growth hormone in the relationship between serum IGF and insulin status was revealed by the experiments of Heinze et al. (70). Hypophysectomized rats were injected with glibenclamide, a sulphonylurea, which enhanced the release of pancreatic insulin. This was accompanied by an increase in serum levels of IGF, relative to those found in intact rats, and to an increase in the width of the tibial epiphysis, clearly showing that insulin could modulate IGF release independently of growth hormone. Probably this is the predominant mechanism for the growth retardation in experimental diabetes.

Tissue anabolism during chemically induced diabetes is impaired not only by a failure of IGF release, but also from the presence of inhibitory factors which oppose the biological actions of both IGF and insulin. Sera from rats in severe catabolic states resulting from diabetes, malnutrition, or hypophysectomy contained proteins which inhibited the IGF-dependent stimulation of glycosaminoglycan synthesis in cartilage explants as well as the ability of insulin to stimulate glucose uptake into isolated rat diaphragm muscle $(71-73)$. The inhibitor is not specific to insulin and insulin-like peptides but has a general depressive effect on all aspects of cartilage metabolic function; it has been partially purified as a heat-labile protein of $21-24 \mathrm{~K}$ daltons molecular weight with an acidic isoelectric point $(72,74)$. In the diabetic rat this inhibitor appears to originate mainly in the liver (75).

\section{INSULIN DYSFUNCTION AND POSTNATAL GROWTH DISORDER}

Diabetes mellitus in childhood is the most common clinical example of disturbed growth due to abnormal insulin secretion. Growth may be subnormal for months before the diabetes is clinically manifest (1), and after treatment has been initiated, growth is closely linked to the quality of diabetic control (76). Excess dietary carbohydrate coupled with excess insulin can result in brittle control and Mauriac's syndrome in which the child is short, obese, and has a large liver due mainly to fatty infiltration. Growth retardation also may occur in conditions such as leprechaunism (77) and lipoatrophic diabetes (78) in which there is a resistance to the action of insulin due to a deficit of insulin receptors.

Winter et al. (79) clarified the endocrinopathy of Mauriac's syndrome by a careful study of a 7-yr-old boy. The patient had a normal plasma growth hormone response to insulin hypoglycemia, but his circulating IGF levels were in the hypopituitary range. The serum IGF rose on each of two occasions when metabolic control was improved. The authors speculated that a block in the growth hormone/IGF axis existed in uncontrolled diabetes; this view was supported by failure of exogenous growth hormone administration to raise a low serum IGF in a second patient with Mauriac's syndrome.

Whether the less severe metabolic abnormalities that often occur in relatively well controlled, insulin-dependent diabetics are detrimental to growth potential is not clearly understood. Diabetic members of identical twin pairs consistently had a lower 
adult height than their nondiabetic brothers or sisters (80). Using various bioassay techniques, circulating IGF in insulin-dependent diabetics was demonstrated to be higher (81), similar to (82), or lower (76) than that in normal adults. The interpretation of these findings is difficult because of the possible interaction of circulating inhibitor in the bioassay. Winter et al. (76) reported that there was an inverse correlation between the serum IGF determined by bioassay and the glycosylated hemoglobin level in 40 insulin-dependent diabetic children, and suggested that poor metabolic control may adversely affect growth endocrinology. When IGF I and II were measured by radioimmunoassay in insulin-dependent children, adults, and control subjects, no differences in mean circulating levels were observed, despite the plasma growth hormone levels being raised in the diabetic children $(83,84)$. The authors suggested that the IGF response to growth hormone may be blunted in the diabetic child, but they failed to take into account that many of their patients were pubertal, a time when both IGF and growth hormone levels may be higher than in adult life.

A most informative study on the growth potential of the relatively well-controlled diabetic child was provided by Rudolf et al. (85) who measured growth velocity in nine insulin-dependent children before and after 6 months of intense insulin treatment using pumps or multiple injections. During conventional therapy (once or twice daily injections of insulin) the mean growth velocity was $5.3 \mathrm{~cm} / \mathrm{yr}$, e.g. within the normal range, despite evidence of spasmodic hyperglycemia. After a period of intense management, in which the overall dose of insulin was not increased, mean plasma glucose fell from 270 to $105 \mathrm{mg} / \mathrm{dl}$ and glycosylated hemoglobin from 12.4 to $8.4 \%$; mean growth velocity increased sharply to $9.4 \mathrm{~cm} / \mathrm{yr}$ as the serum IGF I level increased 2-fold. The rate of skeletal maturation did not increase. It was concluded that improved metabolic control, even for children who were not obviously short, could substantially increase adult height potential. A recent follow-up study examined the circulating IGF I and II levels in diabetic children by specific radioimmunoassays (86); during conventional therapy IGF I was lower, but IGF II was generally unaltered in 19 insulin-dependent diabetics compared to nondiabetic controls. Following 1 wk of intensive insulin therapy, IGF I values increased by $25 \%$ despite a decrease in the mean 24-h levels of growth hormone. Circulating IGF II did not alter during intensive therapy. This study provided further evidence that the normal control of IGF I by growth hormone is disrupted during diabetes and that this can be partially corrected by improved metabolic control. In contrast endogenous hyperinsulinemia in childhood is not associated with a serious disturbance of growth endocrinology. Blethen et al. (87) described seven children aged below 3 yr with severe fasting hypoglycemia due to hyperinsulinemia. Neither IGF I nor II differed from the values for age-matched control children.

Disorders arising from insulin resistance are heterogeneous and can involve both receptor and postreceptor abnormalities. Those resulting in growth retardation are seen at their most extreme in leprechaunism. This condition is typified by severe intrauterine and postnatal growth retardation with decreased subcutaneous fat and decreased muscle mass. Hyperinsulinism and $\beta$ cell hyperplasia sometimes may be present. Taylor et al. (88) described a patient with extreme insulin resistance whose lymphocytes bound insulin with high affinity but showed abnormal binding in response to changes of temperature and $\mathrm{pH}$. A defect in the affinity of the insulin receptor was postulated. Kaplowitz and D'Ercole (89) cultured skin fibroblasts from a leprechaun infant and observed apparently normal binding of insulin and IGF I but reduced proliferation in vitro. The uptake of glucose and amino acids and the incorporation of thymidine into DNA were abnormally low in response to both insulin and IGF I as well as to epidermal growth factor, suggesting that a common postreceptor defect existed for a variety of anabolic hormones.

A defect originating from a receptor abnormality also was described by Schilling et al. (90) in an infant with hyperinsulinemia and insulin resistance who died at age $7 \mathrm{wk}$. Although fibroblasts from the baby were able to bind epidermal growth factor normally they did not bind insulin, and insulin was unable to promote intracellular glucose uptake. The cells of 2 similar patients, reported by Knight et al. (77), were unable to transport glucose but did transport amino acids in vitro in response to either insulin or MSA. From the handful of case studies so far reported it is clear that insulin resistance, at either a receptor or postreceptor level, is seldom isolated from a resistance to the biological actions of other peptide growth factors, which together result in intracellular malnutrition, impaired growth and frequently early death.

Insulin resistance originating from various lesions at and beyond the insulin receptor also underlies the syndrome of lipoatrophic diabetes. This syndrome is characterized by a lack of adipose tissue and abnormalities of carbohydrate and lipid metabolism (78). The molecular basis of one form of insulin resistance was recently described in patients with a type A syndrome (91). This occurred in young, nonobese women with extreme hyperinsulinemia and a resistance to exogenous insulin. A congenital defect was identified in the insulin receptor protein kinase activity of circulating monocytes and lymphocytes following chemical transformation in vitro.

Conversely, increased sensitivity to insulin has been reported for cultured skin fibroblasts from patients with insulin- or noninsulin-dependent diabetes (92). Cells derived from diabetic patients showed a greater sensitivity to insulin than those from nondiabetics with respect to collagen synthesis. This may have important implications for the etiology of macroangiopathy in diabetes, since collagen comprises more than half the total protein present in human atherosclerotic plaques (93). Fibrous deposition in diabetic patients may originate from smooth muscle cells which proliferate in the subintima and deposit forms of collagen chemically distinct from those found in normal subjects (94). Insulin-dependent diabetic subjects with atherosclerosis were found to have higher circulating insulin levels than those without diabetes (95).

\section{INSULIN AS A FETAL GROWTH FACTOR}

Abnormal insulin secretion in utero can have profound physical consequences for the newborn infant. These have been best documented in the infant of the poorly controlled diabetic mother who is abnormally heavy, obese, may have visceromegaly, and be longer than appropriate controls of the same gestational age (96). Pedersen et al. (97) were the first to suggest that these somatic changes resulted from maternal hyperglycemia causing fetal hyperglycemia which provoked increased fetal insulin secretion. The metabolic disturbances in diabetic pregnancy are now appreciated to be more complex (98), and other classes of metabolites, notably amino acids, are thought to exert a trophic effect on the development of the fetal B-cell as well as being insulin secretogogues (99).

Although insulin is present in the human fetal pancreas from 10 wk gestation, insulin release remains glucose insensitive until approximately $28 \mathrm{wk}$ gestation age $(100)$, at which time the preadipocyte matures into an insulin-sensitive cell that is capable of accumulating lipid. Most of the excess weight gain seen in the infant of a diabetic mother is fat which is accumulated in the last trimester of pregnancy. The less dramatic but unequivocal increase in somatic growth occurring concurrently suggests that insulin has an additional direct or indirect role in protein synthesis and cellular proliferation. Enhanced fetal somatic development has been described in infants with nesidioblastosis or the Beckwith-Wiedemann syndrome, each of which is associated with hypersecretion of insulin $(101,102)$. Conversely, in transient neonatal diabetes (103) and in pancreatic agenesis (104), the newborn infant is characteristically small-for-dates having poor muscle bulk and virtually no adipose tissue. 
There are several pathways by which insulin can act as a fetal growth factor. First, it may alter cellular nutrition to increase nutrient uptake and utilization. Second, insulin may exert a direct anabolic action via either the insulin or type I IGF receptor. Third, insulin may modulate the release of IGF or other growth factors from fetal tissues. A direct association between plasma insulin levels and fetal body weight was reported in the rat (105) and rabbit (106). Insulin and IGF receptors were identified in human fetal tissues from at least 15 wk gestation; insulin receptor number increased with gestational age until $25 \mathrm{wk}$, after which time binding capacity was enhanced by an increase in receptor affinity only (107). In the embryonic chick, tissue receptors for insulin were apparent from 3 days of incubation, and insulin itself was detectable as early as the 2 nd day $(108,109)$. Hence, both hormone and receptor are present before the known time of pancreatic islet development in the chick (about 5 days) (110).

At term, both insulin binding and affinity of rat liver membrane exceeded adult values (107). Additionally, monocytes from receptor cord blood of normal human infants had five times the insulin binding capacity of adult cells, and monocytes taken from cord blood of infants of diabetic mothers were increased still further $(111,112)$. While we found no direct mitogenic action of insulin on human fetal fibroblasts or myoblasts obtained from fetuses less than 20 wk gestation (Hill DJ, unpublished data), it is conceivable that in later fetal development insulin may exert a direct growth-promoting action. We demonstrated this in isolated fetal rat myoblasts which incorporate tritiated thymidine at an enhanced rate in the presence of physiological amounts of insulin during a narrow corridor of development at the end of gestation (114). Since the insulin receptor population may be abnormally elevated in some tissues from the infant of the diabetic mother, this coupled with hyperinsulinemia may result in a direct, pathophysiological stimulation of human fetal somatic and skeletal growth.

There have been several attempts to reproduce, in the animal model, the overgrowth seen in the human infant of a diabetic mother. Injection of the fetal rat with insulin in late gestation, after extension of pregnancy by treatment of the dam with progesterone, resulted in increased fetal weight and nitrogen content (115). The postmature fetus was capable of laying down adipose tissue, and this was greater in fetuses exhibiting an induced hyperinsulinemia than in fetuses from control animals (116). However, the model is unavoidably unphysiological since the rat does not normally lay down subcutaneous fat until after birth. The induction of hyperinsulinemia in the fetal rat or rabbit, either by making the mother mildly diabetic or by direct injection of insulin into the fetus, led to an elevation of circulating IGF levels and increased tissue metabolic activity $(118,119)$. In these short-term experiments no significant increase in fetal body size was observed. Chronic fetal hyperinsulinemia and a careful selection of experimental species is necessary to demonstrate an action of insulin on somatic growth.

Susa et al. (120) implanted osmotic minipumps containing insulin into monkey fetuses. Three weeks of pharmacological hyperinsulinemia resulted in a $34 \%$ increase in fetal body weight associated with enlargement of the heart, liver, and spleen, but not the lung, kidney, or brain. Despite serum insulin levels in excess of $20 \mathrm{nM}$ the fetuses remained euglycemic. In subsequent studies (121) a less extreme fetal hyperinsulinemia was produced, and this caused a $23 \%$ increase in body weight; however, the only organ found to be enlarged was the heart suggesting that most of the excess weight was due to large deposits of adipose tissue which were observed but not quantitated. No acceleration of skeletal development was noted in either group of fetuses. We used osmotic minipumps to make fetal pigs hyperinsulinemic for $2 \mathrm{wk}$ late in gestation (122). No increase in total body weight or length was found, but the experimental animals did manifest an increase in tissue glycogen stores and in the RNA/DNA ratio of skeletal muscle. The susceptibility of different species to fetal hyperinsulinemia may be related to the stage of development at which insulin secretion becomes glucose responsive and tissue insulin sensitivity occurs. These events happen shortly after birth in the pig (123) and in late fetal life in the monkey (124).

In the monkey studies, circulating IGF I levels were elevated in animals with gross hyperinsulinemia but not in those with moderately elevated levels (125). This was in keeping with the observation that the concentrations of IGF I and II in the cord blood of human infants of diabetic mothers did not differ from those of control infants despite raised levels of cord plasma Cpeptide.

Considering the experimental and clinical evidence available regarding the endocrinology of the overgrowth seen in the infant of the diabetic mother, two deductions seem reasonable: 1) Body length is increased slightly if at all, even in the presence of extremely high insulin levels and a raised IGF level, suggesting that normal fetal growth is taking place close to its maximum potential; 2) modest hyperinsulinemia can result in organomegaly and obesity despite normal circulating IGF values. These effects seem likely to be due to direct anabolic and lipogenic actions of insulin or to be due to another, as yet unidentified, mediator.

Whereas hyperinsulinemia, with or without hyperglycemia, causes only a modest body overgrowth, experimental fetal hypoinsulinemia is invariably associated with severely reduced growth. When hypoglycemia was produced in the rat fetus either by maternal fasting or by ligation of the uterine blood vessels, a pronounced growth retardation was accompanied by a lowering of plasma insulin and IGF levels $(126,127)$. Since the lack of nutrient availability may have been the major factor in limiting growth, it was important to develop an experimental model in which hypoinsulinemia was produced while maintaining euglycemia. This was achieved by Fowden and Comline (128) who pancreatectomized the fetal sheep in utero approximately $3 \mathrm{wk}$ before term. The mean body weight of the pancreatectomized animals was approximately $20 \%$ below that of controls, but was not consistent with a total cessation of growth. The closest clinical observation relates to transient neonatal diabetes mellitus. One affected infant had a low birth weight with low circulating levels of IGF I and insulin, but with normal levels of IGF II (129). Following insulin therapy there was an immediate clinical improvement with a delayed rise in serum IGF I. Where a complete congenital absence of pancreas has been documented, the human infant only achieved the size of a normal 30-wk-old fetus by term (a birth weight of $1.28 \mathrm{~kg}$ ); there was an absence of adipose tissue and very poor development of muscle mass (104).

The parallel changes in serum insulin and IGF levels, especially during fetal growth retardation, suggest that some of the anabolic actions of insulin in utero may be mediated by a change in IGF release (130). In the fetuses of many species, including man, body growth and circulating IGF levels do not depend on the presence of pituitary growth hormone, and persist after experimental decapitation or hypophysectomy of the rabbit or sheep, respectively $(131,132)$. The immaturity of the growth hormone/ IGF axis may be related to the observations that somatotropic receptors do not appear in the liver of the sheep or rat until after birth $(133,134)$. Any regulation of IGF release by insulin prenatally is therefore unlikely to be mediated by changes in growth hormone secretion or by changes in the nature of the growth hormone receptors.

Similarly, in the two studies so far reported, insulin did not directly alter the release of MSA from fetal rat liver explants (135), or the release of rat IGF I from cultured fetal rat myoblasts (114). The mechanisms that link insulin and IGF in vivo are therefore obscure, but could perhaps involve nutrient availability. In the fetus, IGF are likely to act predominantly in a paracrine rather than an endocrine mode since multiple, isolated fetal animal tissues release IGF peptides independently of a central control by growth hormone (136-138). The IGF found in the fetal circulation may represent the spillover from IGF synthesis in a variety of tissues. It is possible that parallel changes in 
circulating IGF and insulin are the consequence of an altered nutritional environment of the fetal tissues, which may be more susceptible to hypoglycemia than to hyperglycemia.

An interesting and novel approach to the control of fetal growth was provided by Cooke and colleagues $(139,140)$ who transplanted paws from 15-day-old rat fetuses under the kidney capsule of syngeneic young host rats, where they continued to grow and underwent limited ossification. When the host rat was diabetic, the growth of transplants was reduced by approximately $40 \%$ compared to controls, but was almost completely restored following treatment of the host with insulin. Hypophysectomy of the host, which greatly decreased circulating IGF levels, reduced paw growth by more than $60 \%$. This was reversed by treatment of the rat with growth hormone, but not by the injection of insulin. When intact hosts were given insulin injections together with frequent glucose loads to combat hypoglycemia, paw size could not be further increased. These studies indicate several mechanisms governing the growth of fetal tissues and corroborate the evidence from whole animal and in vitro studies. 1) The fetal tissues continued to grow, although at a reduced rate, in the IGF-deficient hypophysectomized rat while the growth of the host animal was completely arrested. This is consistent with a high endogenous growth capacity in the fetal tissues, perhaps mediated by an endogenous production of growth factors. 2) While the development of the fetal tissue was suboptimal in the absence of insulin, the major part of growth was dependent on factors other than insulin, including the IGF. 3 ) In the absence of these other factors insulin alone could not promote growth, and excess insulin could not further enhance fetal growth above that achieved when factors such as the IGF were optimal, regardless of the availability of glucose.

\section{CONCLUSIONS}

Insulin functions as a growth factor both at the level of the cell and in the context of the whole body, yet for many tissues insulin does not appear to be the major circulating anabolic agent. The secondary position of insulin in the endocrine control of mammalian growth may derive from a diversification of biological function among the insulin-related family of molecules. In most mammalian species the IGF and predominantly IGF I, have evolved as the more potent mitogenic peptides while insulin fulfills a more acute metabolic function. Similarly the type I IGF receptor has become the most utilized initiator of a positive pleiotypic response rather than the related insulin receptor. However, this is a gross generalization and for particular tissues, such as the liver, insulin still may act as a potent mitogen via the insulin receptor. Additionally, insulin may continue to exert control of the development of skeletal tissues, in association with intracellular nutrition, by regulating IGF release. Pathophysiologically, insulin may assume the role of a major growth promoting agent if overproduction is associated with extensive binding to the type I IGF receptor, as may occur in the infant of the diabetic mother.

Acknowledgments. The reviewed studies which were carried out by the authors and their colleagues were supported financially by the British Diabetic Association, Yorkshire Cancer Research Campaign, Nuffield Foundation, Hawley Trust, Birthright, and the Medical Research Council.

\section{REFERENCES}

1. Hoskins PJ. Leslie RDG. Pyke DA 1985 Height at diagnosis of diabetes in children: A study in identical twins. B Med J 290:278-280

2. Gillmer MD. Oakley NW, Persson B 1984 Diabetes mellitus and the fetus In: Beard RW, Nathanielsz PW (eds) Fetal Physiology and Medicine, 2nd ed. Marcel Dekker Inc, New York, pp 211-254

3. Salter J Best CH 1953 Insulin as a growth hormone. Br Med J 2:353-356

4. Zapf J, Rindercknecht E, Humbel RE, Froesch ER 1978 Non-suppressible insulin-like activity (NSILA) from human serum: Recent accomplishments and their physiological implications. Metabolism 27:1803-1828
5. Scheonle E, Zapf J, Humbel RE, Froesch ER 1982 Insulin-like growth factor I stimulates growth in hypophysectomized rats. Nature 296:252-253

6. Marquardt H. Todaro GJ, Henderson LE, Oroszlan S 1981 Purification and primary structure of a polypeptide with multiplication-stimulating activity from rat liver cell cultures. Homology with human insulin-like growth factor II. J Biol Chem 256:6859-6865

7. Zapf J, Schoenle E, Froesch ER 1978 Insulin-like growth factors I and II: some biological actions and receptor binding characteristics of two purified constituents of nonsuppressible insulin-like activity of human serum. Eur $J$ Biochem 87:285-296

8. Sato GH, Pardee AB, Sirbasku DA (eds) 1982 Growth of Cells in Hormonally Defined Media. Cold Spring Harbor Laboratory, Cold Spring Harbor, NY.

9. Gorden P, Carpentier JL, Moule ML, Yip CC, Orci L 1982 Direct demonstraton of insulin receptor internalization. A quantitative electron microscopic study of covalently bound ${ }^{125}$ I-photoreactive insulin incubated with isolated hepatocytes. Diabetes 31:659-662

10. Schechter Y 1983 Bound lectins that mimic insulin produce persistent insulinlike activities. Endocrinology 113:1921-1926

11. Van Obberghen E, Spooner PM, Kahn CR, Chernick SS, Garrison MM, Karlsson FA, Grunfeld C 1979 Insulin-receptor antibodies mimic a late insulin effect. Nature 280:500-502

12. Jacobs S, Cuatrecasas $P 1982$ Insulin receptors and insulin receptor antibodies: Structure-function relationships. In: Receptors, Antibodies and Disease. Ciba Foundation Symposium 90, Pitman, London, pp 82-90

13. Massague J, Czech MP 1982 The subunit structures of two distinct receptors for insulin-like growth factors I and II and their relationship to the insulin receptor. J Biol Chem 257:5038-5045

14. Stuart CA, Pietrzyk R, Siu AK, Furlanetto RW 1984 Size discrepancy between somatomedin-C and insulin receptors. J Clin Endocrinol Metab 58:1-5

15. Rechler MM, Podskalny JM, Nissley SP 1976 Interaction of multiplicationstimulating activity with chick embryo fibroblasts demonstrates a growth receptor. Nature 259:134-136

16. Rechler MM, Podskalny JM, Nissley SP 1977 Characterization of the binding of multiplication-stimulating activity to a receptor for growth polypeptides in chick embryo fibroblasts. J Biol Chem 252:3898-3910

17. King GL, Kahn CR, Rechler MM, Nissley SP 1980 Direct demonstration of separate receptors for growth and metabolic activities of insulin and multiplication-stimulating activity (an insulin-like growth factor) using antibodies to the insulin receptor. J Clin Invest 66:130-140

18. Osbourne CK, Monaco ME, Lippman ME, Kahn CR 1978 Correlation among insulin binding, degredation, and biological activity in human breast cancer cells in long-term culture. Cancer Res 38:94-102

19. Barnes D, Sato G 1980 Methods for growth of cultured cells in serum-free medium. Anal Biochem 102:255-270

20. Nagarajan L, Anderson WB 1982 Insulin promotes the growth of F9 embryonal carcinoma cells apparently by acting through its own receptor. Biochem Biophys Res Comm 106:974-980

21. Nagarajan L, Nissley SP, Rechler MM, Anderson WB 1982 Multiplication stimulating activity stimulates the multiplication of F9 embryonal carcinoma cells. Endocrinology 110:1231-1237

22. Koch KS, Shapiro S, Skelly H, Leffert HL 1982 Rat hepatocyte proliferation is stimulated by insulin-like peptides in defined medium. Biochem Biophys Res Commun 109:1054-1060

23. Rizzino A, Crowley C 1980 Growth and differentiation of embryonal carcinoma cell line F9 in defined media. Proc Natl Acad Sci USA 77:457-461

24. Koontz JW, Iwahashi M 1981 Insulin as a potent, specific growth factor in a rat hepatoma cell line. Science 211:947-949

25. Massague J, Blinderman LA, Czech MP 1982 The high affinity insulin receptor mediates growth stimulation in rat hepatoma cells. J Biol Chem 257:13958-13963

26. Czech MP 1984 Regulatory mechanisms coordinating receptor signal transduction. In: 7th International Congress of Endocrinology. Excerpta Medica International Congress Series 652, Excerpta Medica, Amsterdam, p 7

27. Rechler MM, Zapf J, Nissley SP, Froesch ER, Moses AC, Podskalny JM, Schilling EE, Humbel RE 1980 interactions of insulin-like growth factors I and II and multiplication-stimulating activity with receptors and serum carrier proteins. Endocrinology 107:1451-1459

28. Bucher NL 1982 Thirty years of liver regeneration: A distillate. In: Sato GH, Pardee AB, Sirbasku DA (eds). Growth of Cells in Hormonally Defined Media. Cold Spring Harbor, NY, pp 15-26

29. Bucher NL, Swaffield MN 1975 Synergistic action of glucagon and insulin in relation to hepatic regeneration. Adv Enzyme Regul 13:281-293

30. Richman RA, Claus TH, Pilkis SJ, Friedman DL 1976 Hormonal stimulation of DNA synthesis in primary cultures of adult rat hepatocytes. Proc Natl Acad Sci USA 73:3589-3593

31. Kasuga M, Karlsson FA, Kahn CR 1982 Insulin stimulates the phosphorylation of the 95,000 -dalton subunit of its own receptor. Science 215:185187

32. Roth RA, Cassell DJ 1983 Insulin receptor: evidence that it is a protein kinase. Science 219:299-301

33. Roth RA, Mesirow ML, Cassell DJ 1983 Preferential degredation of the subunit of purified insulin receptor. Effect on insulin binding and protein kinase activities of the receptor. J Biol Chem 258:14456-14460

34. Jacobs S, Cuatrecasas $P 1981$ Insulin receptor: structure and function. Endocr Rev 2:251-263

35. Jacobs S, Kull FC, Shelton Earp H, Svoboda ME, Van Wyk JJ, Cuatrecasas P 1983 Somatomedin-C stimulates the phosphorylation of the $\beta$-subunit of 
its own receptor. J Biol Chem 258:9581-9584

36. Heldin CH, Ek B, Ronnstrand L 1983 Characterization of the receptor for platelet-derived growth factor on human fibroblasts. Demonstration of an intimate relationship with a 185,000 dalton substrate for the platelet-derived growth factor-stimulated kinase. J Biol Chem 258:10054-10061

37. Ushiro H, Cohen S 1980 Identification of phosphotyrosine as a product of epidermal growth factor-activated protein kinase in A-431 cell membranes. J Biol Chem 255:8363-8365

38. Collett MS. Purchio AF. Erikson RL 1980 Avian sarcoma virus-transforming protein, pp $60 \mathrm{src}$ shows protein kinase activity specific for tyrosine. Nature 285:167-169

39. Cohen P 1982 The role of protein phosphorylation in neural and hormonal control of cellular activity. Nature 296:613-620

40. Moolenaar WH, Tsien RY, Van der Saag PT, De Laat SW $1983 \mathrm{Na}^{+} / \mathrm{H}^{+}$ exchange and cytoplasmic $\mathrm{pH}$ in the action of growth factors in human fibroblasts. Nature 304:645-648

41. Moolenaar WH, Tertoolen GJ, De Laat SW 1984 Phorbol ester and diacylglycerol mimic growth factors in raising cytoplasmic pH. Nature 312:371373

42. Kishimoto A. Takai Y, Mori T, Kikkawa U, Nishisuka Y 1980 Activation of calcium and phospholipid-dependent protein kinase by diacylglyceraol, its possible relation to phosphatidylinositol turnover. J Biol Chem 255:22732276

43. Jacobs S. Sahyoun NE, Saltiel AR, Cuatrecasas P 1983 Phorbol esters stimulate the phosphorylation of receptors for insulin and somatomedin-C. Proc Natl Acad Sci USA 80:6211-6213

44. Wool I 1979 The structure and function of eukaryotic ribosomes. Ann Rev Biochem 48:719-754

45. Kulkarni RK. Straus DS 1983 Insulin-mediated phosphorylation of ribosomal protein $\mathrm{S} 6$ in mouse melanoma cells and melanoma fibroblasts hybrids in relation to cell proliferation. Biochim Biophys Acta 762:542-551

46. Stiles CD. Pledger WJ. Tucker RW. Martin RG. Scher CD 1980 Regulation of the Balb/c-3 3 cell cycle: effects of growth factors. J Supramol Struct 13:489-499

47. Van Wyk JJ, Underwood LE, D'Ercole AJ, Clemmons DR, Pledger WJ, Wharton WR, Leof EB 1981 Role of somatomedin in cellular proliferation In: Ritzen M. Aperia A. Hall K. Larsson A, Zetterberg A, Zellerstron R (eds) Biology of Normal Human Growth. Raven Press, New York, pp $223-$ 239

48. Armato V. Draghi E. Andreis PG 1978 Effect of glucagon and insulin on the growth of neonatal rat hepatocytes in primary tissue culture. Endocrinology 102:1155-1166

49. Loef EB, Olashaw NE, Pledger WJ. O'Keefe EJ 1982 Cyclic AMP potentiates down regulation of epidermal growth factor receptors by platelet-derived growth factor. Biochem Biophys Res Commun 109:83-91

50. Clemmons DR, Van Wyk JJ, Pledger WJ 1980 Sequential addition of platelet factor and plasma to Balb/c 3T3 fibroblast cultures stimulates somatomedin-C binding early in cell cycle. Proc Natl Acad Sci USA 77:6644-6648

51. Phillips LS, Young HS 1976 Nutrition and somatomedin Il. Serum somatomedin activity and cartilage growth activity in streptozotocin-diabetic rats. Diabetes 25:516-527

52. Takano K. Hizuka N. Shizume K. Hasumi Y, Kogawa M. Tsushima T 1980 Effect of insulin and nutrition on serum levels of somatomedin $A$ in the rat. Endocrinology 107:1614-1619

53. Baxter RC. Brown AS, Turtle JR 1979 Decrease in serum receptor-reactive somatomedin in diabetes. Horm Metab Res 11:216-220

54. Maes M. Ketelslegers JM. Underwood LE 1983 Low plasma somatomedin$C$ in streptozotocin-induced diabetes mellitus. Diabetes 32:1060-1069

55. Phillips LS. Herington AC. Karl IE, Daughaday WH 1976 Comparison of somatomedin activity in perfusates of normal and hypophysectomized rat livers with and without added growth hormone. Endocrinology 98:606-614

56. Francis MJO, Hill DJ 1975 Prolactin-stimulated production of somatomedin by rat liver. Nature 255:167-168

57. Tannenbaum GS 1981 Growth hormone secretory dynamics in streptozotocin diabetes: evidence of a role for endogenous circulating somatostatin. Endocrinology 108:76-82

58. Eigenmann JE, Becker M, Kammermann B, Leemann W, Heimann R, Zapf J. Froesch ER 1977 Decrease of non-suppressible insulin-like activity after pancrcatectomy and normalization by insulin therapy. Acta Endocrinol $85: 818-822$

59. Kagawa M, Takano K. Asakawa K. Hizuka N. Tsushima T, Shizume K 1983 Insulin stimulation of somatomedin A production in monolayer cultures of rat hepatocytes. Acta Endocrinol 103:385-390

60. Binoux M, Hossenlopp P. Lassere C. Sevrin D 1980 Somatomedin production by rat liver in organ culture. 1 . Validity of technique. Influence of the released material on cartilage sulphation. Effects of growth hormone and insulin. Acta Endocrinol 93:73-82

61. Binoux M. Lassere C. Hardouin N 1982 Somatomedin production by rat liver in organ culture III. Studies on the release of insulin-like growth factor and its carrier protein measured by radioligand assays. Effects of growth hormone, insulin and cortisol. Acta Endocrinol 99:422-430

62. Daughaday WH. Phillips LS. Mueller MC 1976 The effects of insulin and growth hormone on the release of somatomedin by the isolated rat liver. Endocrinology 98:1214-1219

63. Miller LL. Schalch DS. Draznin B 1981 Role of the liver in regulating somatomedin activity: effects of streptozotocin diabetes and starvation on the synthesis and release of insulin-like growth factor and its carrier protein by the isolated perfused rat liver. Endocrinology 108:1265-1271

64. Baxter RC, Bryson JM, Turtle JR 1980 Somatogenic receptors of rat liver: regulation by insulin. Endocrinology 107:1176-1181

65. Phillips LS, Young HS 1976 Nutrition and somatomedin 1. Effect of fasting and refeeding on serum somatomedin activity and cartilage growth activity in rats. Endocrinology 99:304-314

66. Clemmons DR, Klibanski A, Underwood LE, McArthur JW, Ridgway EC, Beitins IZ, Van Wyk JJ 1981 Reduction of plasma immunoreactive somatomedin C during fasting in humans. J Clin Endocrinol Metab 53:124\%1250

67. Caufriez A, Golstein J, Lebrun P, Herchuelz A, Furlanetto R, Copinschi i 1984 Relations between immunoreactive somatomedin $\mathrm{C}$, insulin and $\mathrm{T} 3$ patterns during fasting in obese subjects. Clin Endocrinol 20:67-70

68. Picard F, Postel-Vinay MC 1983 Hypophysectomy enhances growth hormone binding sites in liver membranes of male rats. Acta Endocrinol 103:210

69. Baxter RC, Zaltsman Z, Turtle JR 1984 Rat growth hormone (GH) but not prolactin (PRL) induces both GH and PRL receptors in female rat liver. Endocrinology 114:1893-1901

70. Heinze E, Ranke M, Manske E, Vetter U, Voiet KH 1982 The effect of glibenclamide on plasma insulin, plasma somatomedin bioactivity and skeletal growth in hypophysectomized rats. Acta Endocrinol 101:187-192

71. Phillips LS, Belosky DC, Young HS, Reighard LA 1979 Nutrition and somatomedin VI. Somatomedin activity and somatomedin inhibitory activity in sera from normal and diabetic rat. Endocrinology 104:1519-1524

72. Bomboy JD, Burkhalter VJ, Nicholson WE, Salmon WD 1983 Similarity of somatomedin inhibitor in sera from starved, hypophysectomized, and diabetic rats: distinction from a heat-stable inhibitor of rat cartilage metabolism. Endocrinology 112:371-377

73. Phillips LS, Scholz TD 1982 Nutrition and somatomedin IX. Blunting of insulin-like activity by inhibitor in diabetic rat serum. Diabetes 81:97-104

74. Phillips LS, Bajaj VR, Fusco AC, Matheson CK 1983 Nutrition and somatomedin XI. Studies of somatomedin inhibitors in rats with streptozotocininduced diabetes. Diabetes 32:262-264

75. Vassilopoulou-Sellin R, Oyedeji CO, Samaan NA 1983 Somatomedin inhibitors in serum and liver of growth hormone-deficient diabetic rats. Diabetes 32:262-264

76. Winter RJ, Phillips LS, Klein MN, Traisman HS, Green OC 1979 Somatomedin activity and diabetic control in children with insulin-dependent diabetes. Diabetes 28:952-954

77. Knight $\mathrm{AB}$, Rechler MM, Romanus JA, Van Obberghen-Schilling EE, Nissiey SP 1981 Stimulation of glucose incorporation and amino acid transport by insulin and an insulin-like growth factor in fibroblasts with defective insulin receptors cultured from a patient with leprechaumism. Proc Natl Acad Sci USA 78:2554-2558

78. Wachslicht-Rodbard H, Muggeo M, Kahn CR, Saviolakis GA, Harrison LE, Fleir JS 1981 Heterogeneity of the insulin-receptor interaction in lipostrophic diabetes. J Clin Endocrinol Metab 52:416-425

79. Winter RJ, Phillips LS, Green OC, Traisman HS 1980 Somatomedin activity in the Mauriac Syndrome. J Pediatr 97:598-600

80. Tattersall RB, Pyke DA 1973 Growth in diabetic children: studies in identical twins. Lancet 2:1105-1109

81. Cohen MP, Jasti K, Rye DL 1977 Somatomedin in insulin-dependent diabetes mellitus. J Clin Endocrinol Metab 45:236-239

82. Nash H 1979 Growth failure, somatomedin and growth hormone levels in juvenile diabetes mellitus-a pilot study. Aust NZ J Med 9:245-249

83. Lamberton RP, Goodman AD Kassoff A, Rubin CL, Treble DH, Saba TM, Merimee TJ, Dodds Wj 1984 Von Willebrand Factor (VIII R:AG), fibro nectin, and insulin-like growth factors I and II in diabetic retinopathy and nephropathy. Diabetes 33:125-129

84. Horner JM, Kemp SF, Hintz RL 1981 Growth hormone and somatomedin in insulin-dependent diabetes mellitus. J Clin Endocrinol Metab 53:1148. 1153

85. Rudolf MC, Sherwin RS, Markowitz R, Bates SE, Genel M, Hochstadt J, Tamborlane WV 1982 Effect of intensive insulin treatment on linear growth in the young diabetic patient. J Pediatr 101:333-339

86. Amiel SA, Sherwin RS, Hintz RL, Gertner JM, Press CM, Tamborlane WV 1984 Effect of diabetes and its control on insulin-like growth factors in the young subject with type I diabetes. Diabetes 33:1175-1179

87. Blethen SL, White NH, Santiago JV, Daughaday WH 1981 Plasma somatomedins in children with hyperinsulinism. J Clin Endocrinol Metab 52:748. 750

88. Taylor SI, Hedo JA, Underhill LH, Kasuga M, Elders MJ, Roth J 1982 Extreme insulin resistance in association with abnormally high binding affinity of insulin receptors from a patient with leprechaunism: Evidence for a defect intrinsic to the receptor. J Clin Endocrinol Metab 55:1108. 1113

89. Kaplowitz PB, D'Ercole AJ 1982 Fibroblasts from a patient with leprechaunism are resistant to insulin, epidermal growth factor, and somatomedin-C. $J$ Clin Endocrinol Metab 55:741-748

90. Schilling EE, Rechler MM, Grunfeld C, Rosenberg AM 1979 Primary defect of insulin receptors in skin fibroblasts cultured from an infant with leprechaunism and insulin resistance. Proc Natl Acad Sci USA 76:5877-.5881

91. Grunberger G, Comi RJ, Taylor SI, Gorden P 1984 Tyrosine kinase activity of the insulin receptor of patients with type A extreme insulin resistance: studies with circulating mononuclear cells and cultured lymphocytes. J Clin Endocrinol Metab 59:1152-1158

92. Kjellstrom $\mathbf{T}$, Malmquist $\mathbf{J} 1984$ Insulin effects on collagen and protein 
production in cultured human skin fibroblasts from diabetic and nondiabetic subjects. Horm Metab Res 16:168-171

93. Stout RW 1979 Diabetes and atherosclerosis-the role of insulin. Diabetologia $16: 141-150$

94. Termi R. Tavella D. Donnelly P. Di Ferrante N. Hill L. Lynn C. Hatton D 1980 Cultured fibroblasts of juvenile diabetics have excessively soluble pericellular collagen. Biochem Biophys Res Comm 92:1071-1075

95. Santen RJ, Willis PW. Fajans SS 1972 Atherosclerosis in diabetes mellitus. Arch Intern Med 130:843-883

96. Pederson J 1977 The Pregnant Diabetic and Her Newborn, 2nd ed. Williams \& Wilkins. Baltimore

97. Pederson J, Bojsen-Moller B, Poulsen H 1954 Blood sugar in newborn infants of diabetic mothers. Acta Endocrinol 15:33-52

98. Freinkel N, Metzger BE 1979 Pregnancy a tissue culture experience: the critical implications of maternal metabolism for fetal development. In: Pregnancy Metabolism. Diabetes and the Fetus. Ciba Foundation Symposium 63, Excerpta Medica, Amsterdam, pp 3-23

99. Milner RDG, De Gasparo M. Milner GR. Wirdnam PK 1979 Amino acids and development of the beta cell. In: Sutherland HW, Stowers JM (eds) Carbohydrate Metabolism in Pregnancy and the Newborn 1978. SpringerVerlag. Berlin. pp 132-151

100. Milner RDG 1974 Growth and development of the endocrine glandsendocrine pancreas. In: Davis JA. Dobbing W (eds) Scientific Foundations of Paediatrics. W Heinemann. London. pp 507-513

101. Heitz PV. Kloppel G. Hacki WH 1977 Nesidioblastosis: The pathologic basis of persistant hyperinsulinaemic hypoglycaemia in infants. Diabetes $26: 632$ 642

102. Filippi G. McKusick VA 1970 The Beckwith-Weidemann syndrome. Medicine 49:279-298

103. Schiff D. Colle E. Stern L 1972 Metabolic and growth patterns in transient neonatal diabetes. $N$ Engl J Med 287:1 19-122

104. Hill DE 1978 Effect of insulin on fetal growth. Semin Perinatol 2:319-328

105. Girard JR Ricutort M Kervran A. Jost A 1976 Hormonal control of fetal growth with particular reference to insulin and growth hormone. In: Rooth G. Brateby LE (eds) Perinatal Medicine. Almquist and Wiksell. Stockholm. pp 197-202

106. Fletcher JM. Falconer J. Bassett JM 1982 The relationship of body and placental weight to plasma levels of insulin and other hormones during development in fetal rabbits. Diabetologia 23:124-130

107. Sara VR. Hall K. Misaki M. Fryklund L. Christensen L. Wetteberg L 1983 Ontogenesis of somatomedin and insulin receptors in the human fetus. $\mathrm{J}$ Clin Invest 71:1084-1094

108. Hendricks A. De Pablo F. Roth J 1984 Early development and tissue-specific patterns of insulin binding in chick embryos. Endocrinology 115:1315 1323

109. De Pablo F. Roth J. Hernandez E, Pruss RM 1982 Insulin is present in chicken eggs and early chick embryos. Endocrinology 111:1909-1916

110. Benzo CA. Green TD 1974 Functional differentiation of the chick endocrine pancreas: insulin storage and secretion. Anat Rec 180:491-496

111. Thorsson AV. Hintz RL 1977 Insulin receptors in the newborn, increase in receptor affinity and number. N Engl J Med 297:908-912

112. Neufeld ND Kaplan SA. Lippe BM 1981 Monocvte insulin receptors in infants of strictly controlled diabetic mothers. J Clin Endocrinol Metab $52: 473-478$

113. Deleted in proof

114. Crace CJ. Hill DJ. Milner RDG 1984 Mitogenic actions of insulin on fetal and neonatal rat cells in vitro. J Endocrinol 104:63-68

115. Picon L 1967 Effect of insulin on growth and biochemical composition of the rat fetus. Endocrinology 81:1419-1421

116. Ktorza A. Nurjhan N. Girard JR. Picon L 1983 Hyperglycaemia induced by glucose infusion in the unrestrained pregnant rat: effect on body weight and lipid svnthesis in post mature fetuses. Diabetologia 24:128-130

117. Hill DI. Sheffrin RA. Milner RDG 1982 Raised plasma somatomedin activity and cartilage metabolic activity $\left({ }^{35} \mathrm{~S}\right.$ sulphate uptake in vitro) in the fetus of mildly diabetic pregnant rats. Diabetologia 23:270-274

118. D'Ercole AJ. Bose CL. Underwood LE. Lawson EE 1984 Serum somatome- din- $C$ concentrations in a rabbit model of diabetic pregnancy. Diabetes 33:590-595

119. Hill DJ, Milner RDG 1980 Increased somatomedin and cartilage metabolic activity in rabbit fetuses injected with insulin in utero. Diabetologia 19:143147

120. Susa JB, McCormick KL, Widness JA, Singer DB, Oh W, Adamsons K, Schwartz R 1979 Chronic hyperinsulinaemia in the fetal rhesus monkey: effects on fetal growth and composition. Diabetes 28:1058-1063

121. Susa JB, Neave C, Sehgal P, Singer DB, Zeller WP, Schwartz R 1984 Chronic hyperinsulinaemia in the fetal rhesus monkey. Effects of physiological hyperinsulinaemia on fetal growth and composition. Diabetes 33:656-660

122 Spencer GSG Hill D Garsson G MacDonald A Collenbrander B 1983 Somatomedin activity and growth hormone levels in body fluids of the fetal pig: effect of chronic hyperinsulinaemia. J Endocrinol 96:107-114

123. Herbein JH, Martin RJ, Griel LC. Kavanaugh JF 1977 Serum hormones in the perinatal pig and the effect of exogenous insulin on blood sugars. Growth 41:277-283

124. Chez RA, Mintz DH, Horger EO, Hutchinson DL 1970 Factors affecting the response to insulin in the normal subhuman pregnant primate. J Clin Invest 49:1517-1527

125. Susa JB, Widness JA, Hintz R, Liu F, Sehgal P, Schwartz R 1984 Somatomedins and insulin in diabetic pregnancies: effects on fetal macrosomia in the human and rhesus monkey. J Clin Endocrinol Metab 58:1099-1105

126. Hill DJ, Fekete M, Milner RDG, De Prins R, Van Assche A 1983 Reduced plasma somatomedin activity during experimental growth retardation in the fetal and neonatal rat. In: Spencer EM (ed) Insulin-Like Growth Factors/ Somatomedins. Basic Chemistry, Biology and Clinical Importance. Walter de Gruyter, Berlin, pp 345-352

127. De Prins FA, Hill DJ, Fekete M, Robsen DJ, Fieller NRJ, Van Assche FA, Milner RDG 1984 Reduced plasma somatomedin activity and costal cartilage sulfate incorporation activity during experimental growth retardation in the rat. Pediatr Res 18:1100-1104

128. Fowden AL, Comline RS 1984 The effects of pancreatectomy on the sheep fetus in utero. J Exp Physiol 69:319-330

129. Blethen SL. White NH, Santiago JV, Daughaday WH 1981 Plasma somatomedins. endogenous insulin secretion, and growth in transient neonatal diabetes mellitus. J Clin Endocrinol Metab 52:144-147

130. Milner RDG, Hill DJ 1984 Fetal growth control: the role of insulin and related peptides. Clin Endocrinol 21:415-433

131. Hill DJ, Davidson P, Milner RDG 1979 Retention of plasma somatomedin activity in the foetal rabbit following decapitation in utero. $J$ Endocrinol 81:93-102

132. Brinsmead MW, Liggins GC 1979 Serum somatomedin activity after hypophysectomy and during parturition in fetal lambs. Endocrinology 105:297305

133. Gluckman PD. Butler J, Elliot T 1983 The ontogeny of somatotropic binding sites in ovine hepatic membranes. Endocrinology 112:1607-1612

134. Maes M, De Hertogh R, Watrin-Granger P. Ketelslegers JM 1983 Ontogeny of liver somatotropic and lactogenic binding sites in male and female rats. Endocrinology 113:1325-1332

135. Fennoy I, Eisen HJ, White RM 1983 The potential of insulin as a regulator of fetal somatomedin production. In: Spencer EM (ed) Insulin-Like Growth Factors/Somatomedins. Basic Chemistry, Biology and Clinical Importance. Walter de Gruyter, Berlin, pp 357-364

136. D’Ercole AJ, Applewhite GT, Underwood LE 1980a Evidence that somatomedin is synthesized by multiple tissues in the fetus. Dev Biol 75:315-328

137. Adams SO Nissley SP Handwerger S, Rechler MM 1983 Development patterns of insulin-like growth factor I and II synthesis and regulation in rat fibroblasts. Nature 302:150-153

138. Hill DJ. Crace CR, Fowler L, Holder AT, Milner RDG 1984 Cultured fetal rat myoblasts release peptide growth factors which are immunologically and biologically similar to somatomedin. J Cell Physiol 119:349-358

139. Cooke PS, Russel SM, Nicoll CS 1983 A transplant system of studying hormonal control of growth of fetal rat tissues: effects of hypophysectomy, growth hormone, prolactin and thyroxine. Endocrinology 112:806-812

140. Cooke PS. Nicoll CS 1984 Role of insulin in the growth of fetal rat tissues. Endocrinology 114:638-643 